\title{
AREAL SURFACE CHARACTERIZATION OF ACID-FRACTURES IN CARBONATE ROCKS
}

\author{
Valdo Ferreira Rodrigues', Rodolfo Araujo Victor ${ }^{2}$, \\ Wellington Campos ${ }^{3}$ and Ana Catarina da Rocha Medeiros ${ }^{1}$ \\ Recebido em 1 março, 2011 / Aceito em 28 junho, 2012 \\ Received on March 1, 2011 / Accepted on June 28, 2012
}

\begin{abstract}
Fracture surface characteristics have significant effect on fracture hydraulic conductivity. The available acid-fracture conductivity correlations do not consider surface characteristics or make an incipient use of it. A proper description of the acid-fracture surfaces is the initial step towards the right consideration of surface roughness in hydraulic conductivity. This paper presents an areal (3D) surface evaluation of acid-etched fractures, simulated in samples taken from whole cores of an oil producer limestone. The topography of acid-fractured surfaces was assessed using a laser profilometer. The surfaces were evaluated with a set of 3D surface parameters. The results showed that the main features of acid-etched surfaces are large roughness, negative skewness, high kurtosis, and intermediate isotropy, mostly random, but with some spatial orientation. The acid-fractured surfaces can be represented by the rms height, which showed great linear correlation with most of the surface parameters. The parameters texture aspect ratio, bearing index, valley retention index, and density of summits showed low correlation with rms height. A method to calculate fracture width from surface topography was developed. An attempt to explain abnormal behavior in initial conductivity tests revealed the potential use of surface characterization for management of fine particles in oil and gas reservoirs. It is suggested to search improved fracture conductivity correlation through the relationship between lab measured conductivities and surface characterization parameters.
\end{abstract}

Keywords: acid-fracture, surface characterization, surface metrology, asperity tribology.

RESUMO. As características das superfícies de fraturas impactam a condutividade hidráulica destas. As correlações de condutividade de fraturas ácidas não levam em conta tais características ou o fazem de forma incipiente. Uma descrição adequada das superfícies das fraturas ácidas é o primeiro passo para que a rugosidade destas superfícies passe a ser corretamente considerada na condutividade hidráulica. Este artigo apresenta uma avaliação abrangente em área (3D) das superfícies de fraturas ácidas simuladas em amostras obtidas de testemunhos inteiriços ( whole cores) de um carbonato produtor de óleo. A topografia das superfícies de fraturas ácidas foi medida com um perfilômetro a laser. As superfícies foram avaliadas através de um conjunto de parâmetros 3D. Os resultados revelaram que as principais características das superfícies de fraturas ácidas são alta rugosidade, assimetria negativa, alta curtose e isotropia intermediária, i.e., predominantemente randômica, mas com alguma orientação espacial. As superfícies de fraturas ácidas podem ser representadas pela média quadrática das alturas da textura, a qual tem alta correlação com a maioria dos parâmetros de superfície. Os parâmetros razão de aspecto da textura, índice de rolamento, índice de retenção de fluido nos vales e densidade de altos revelaram baixa correlação com a média quadrática das alturas. Foi desenvolvido um método de cálculo da largura de fratura a partir da topografia das superfícies. Uma tentativa de explicação do comportamento anormal observado em alguns ensaios de condutividade revelou o potencial do uso de caracterização de superfícies em gerenciamento de partículas finas em reservatórios de óleo e gás. Sugere-se a busca de novas correlações de condutividade de fraturas ácidas através da correlação entre resultados de ensaios de condutividade e parâmetros de caracterização de superfície.

Palavras-chave: fraturamento ácido, caracterização de superfície, metrologia de superfície, tribologia das asperezas.

\footnotetext{
1UENF - Universidade Estadual do Norte Fluminense Darcy Ribeiro, CCT - Centro de Ciências e Tecnologias, LENEP - Laboratório de Engenharia e Exploração de Petróleo, Rodovia Amaral Peixoto, km 163, Avenida Brenand s/n, Imboassica, 27925-310 Macaé, RJ, Brazil. Phone: +55 (22) 2765-6500; Fax: +55 (22) 2765-6565 - E-mails: hmol.valdo@gmail.com; catarina1307@yah0o.com.br

2Escola de Ciências e Tecnologias de E\&P, Universidade Petrobras, G0B7/801-3503, Rua Ulysses Guimarães, 565, Cidade Nova Rio de Janeiro, RJ, Brazil. Phone: +55 (21) 3487-3503 - E-mail: rodolfoav@petrobras.com.br

${ }^{3}$ Petrobras/E\&P, Av. República do Chile, 330, 8 o andar, Centro, 20031-170 Rio de Janeiro, RJ, Brazil. Phone: +55 (21) 2144-1606 - E-mail: wcampos@petrobras.com.br
} 


\section{INTRODUCTION}

Acid fracturing is a well stimulation method used in oil and gas reservoirs of acid soluble rocks. To create an acid-fracture, acid is pumped along a hydraulically induced fracture, leaking off into the formation. After pumping stop, hydraulic pressure falls, the higher fracture faces asperities contact each other and deform under closure stress (Fig. 1). The most important parameters for acid fracturing success are fracture conductivity and fracture length. The current acid-fracture conductivity correlations present low accuracy, so there is a demand for improved correlations.

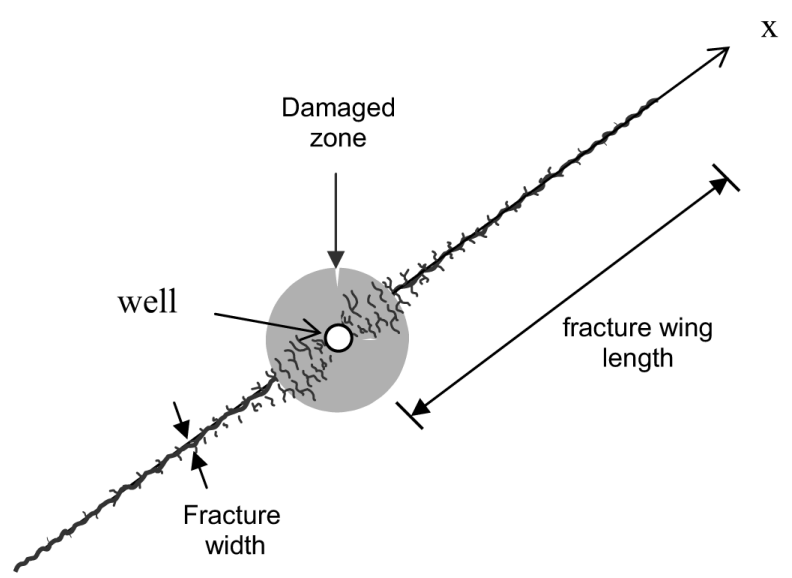

Figure 1 - Schematics of a well stimulated with an acid-fracture. *Out of scale: fracture width highly magnified.

Acid-fracture conductivity depends on fracture width, fracture surface roughness, and fracture faces mismatch. Surface characterization is essential to estimate the roughness effects and can be used to calculate the mechanical width, providing results more accurate than usual lab measurements.

Profile surface characterization has been applied in fracture conductivity studies (Patir \& Cheng, 1978; Brown \& Scholz, 1985; Zimmerman \& Bodvarsson, 1994; Gong et al., 1998). Recent studies applied areal surface characterization in acidfractures with 3D visualization techniques and calculating some 3D parameters (Malagon Nieto, 2007; Pournik, 2008; Antelo et al., 2009). This work differentiates from previous studies by using samples from whole cores of an oil producer limestone, instead of samples from quarries or outcrops, and by evaluating the fracture surfaces with a comprehensive areal surface characterization. A method to calculate fracture width from surface topography was developed. A trial to explain abnormal behavior in initial conductivity tests revealed the potential use of surface characterization for management of fine particles in oil and gas reservoirs.

\section{Parameters selection for areal characterization of acid-fracture surfaces}

The transition from profile to areal characterization has been considered part of the current paradigm shift in surface metrology. The areal characterization tries to identify the fundamental and functional topographical features of the surface. It includes evaluation of texture shape and direction and discrimination between connected and isolated features (Jiang et al., 2007). The study of acid-fractures surfaces is an asperity tribology study according to Holmberg's (2001) categorization.

This study adopted a suit of parameters mostly from the ones proposed in the ISO/TS CD 25178-2 (2006) standard. The parameters selection followed two criteria: address the hydraulic conductivity function and present reliable method of calculus. The selected suit included the amplitude parameters rms height $(\mathrm{Sq})$, height skewness (Ssk), height kurtosis (Sku), maximum peak height (Sp), maximum valley height (Sv), maximum height of texture surface ( $\mathrm{Sz}$ ), and arithmetical mean height (Sa). It also included the spatial parameters: fastest decay auto-correlation length (Sal), texture aspect ratio (Str), and texture direction of the texture surface (Std). Idem the hybrid parameters rms slope of the assessed texture surface (Sdq) and developed interfacial area ratio (Sdr). From the 13 parameters of the so called volume set four were selected: material volume of peaks (Vmp), material volume of the core $(\mathrm{Vmc})$, void volume of the core $(\mathrm{Vvc})$ and void volume of the valleys (Vvv). Three parameters, not included in the standard, were added: surface bearing index (Sbi), core fluid retention index (Sci), valley fluid retention index (Svi). From the nine feature parameters four were selected: density of summits (Sds), ten-point height of surface (S10z), five-point peak height (S5p), and five-point pit height (S5v).

The areal surface texture parameters were calculated on the roughness area after filtering out form and waviness. The filter used is the one recommended in the IS0-13565-1 (1998) standard, proper for surfaces with deep valleys such as the acid wormholes. It was implemented with a moving average algorithm. To calculate the parameters this study implemented the equations presented by Thomas (1999), Mainsah et al. (2001), Whitehouse (2002), and Blunt \& Jiang (2003) with MATLAB codes. The parameters Sal, and Str were obtained with a specific code that first calculated the normalized autocorrelation function, and then the contour line related to the 0.2 decay, and finally calculated its minimum and maximum intercept segments. The minimum segment corresponds to Sal and the minimum to maximum segment ratio corresponds to Str (Tsukada \& Sasajima, 1983, apud Thomas, 1999). 

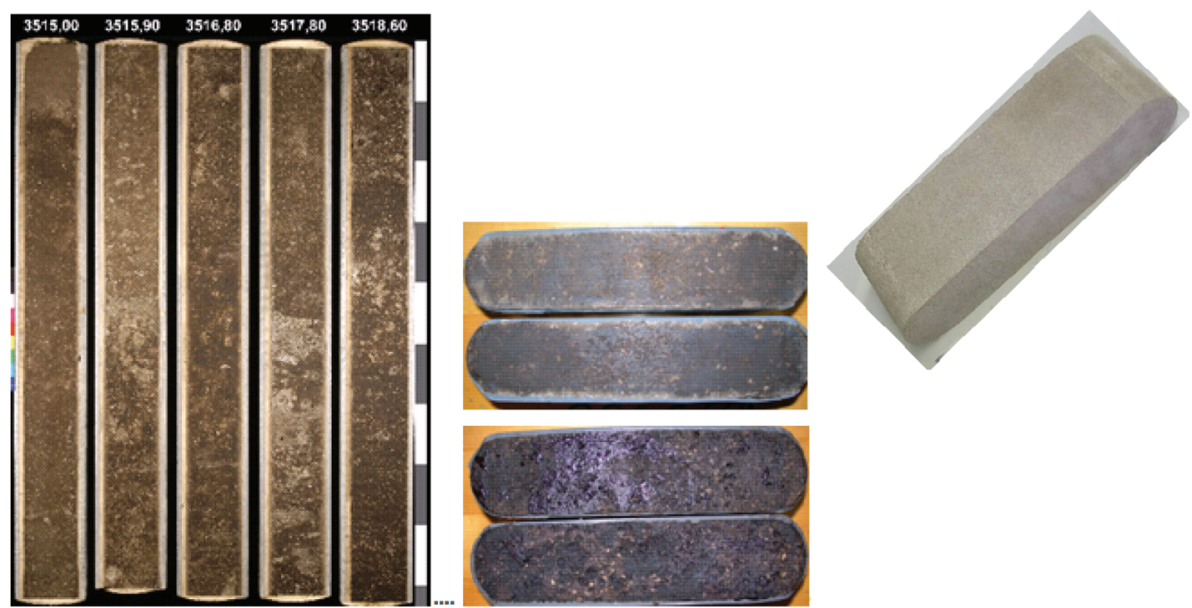

Figure 2 - Core boxes from Quissamã-ESP (left) and top view of samples before (above) and after (below) acid-etching.

\section{Experimental study}

Five meters of whole cores from the Quissamã limestone, Campos Basin, offshore Brazil, drilled from 3,515.5 m to 3,545.5 m depth, were cut and polished to the shape of the modified API cell used for acid-fracture simulation and conductivity tests (Fig. 2). The cores provided 20 samples of $17.78 \mathrm{~cm}$ (7 in) length, $4.44 \mathrm{~cm}$ (1.75 in) height, and $7.62 \mathrm{~cm}$ (3 in) thickness. Then the following sequence of tests was carried out:

1) Profilometer scan of each sample before acid-etching;

2) Rock embedment strength measurement in each sample before acid-etching;

3) Acid-etching along the fracture mimic by each pair of samples;

4) Profilometer scan of each sample after acid-etching.

5) Rock embedment strength measurement in each sample after acid-etching;

6) Conductivity tests.

The injection rate during acid-etching was set at $1.0 \mathrm{~L} / \mathrm{min}$ in all experiments, with a backpressure of $6.89 \mathrm{GPa}(1,000 \mathrm{psi})$. Four acid systems were used: straight $15 \% \mathrm{HCl}$, gelled $15 \% \mathrm{HCl}$, viscoelastic $15 \% \mathrm{HCl}$, and emulsified $\mathrm{HCl}$ at $185^{\circ} \mathrm{F}$. The acid-etching was properly scaled to field conditions based on Reynolds' and on Peclet's dimensionless numbers.

The laser profilometer used to assess surface topography (Fig. 3) had vertical accuracy of $13 \mu \mathrm{m}$ (0.0005 in) and measurement range of $25.4 \mathrm{~mm}$ (1.0 in). All the experiments used a 0.05 inch measurement interval in both directions. The profilometer recorded the scanning data in three columns, two for position and the third for the height, so that each row corresponded to 3D coordinate.

This paper did not address the rock embedment tests and the conductivity tests, as the focus here is surface characterization. However, the results of conductivities measured at zero closure stress were correlated with the surface parameters.

\section{Definition of the area of analysis}

Some artifacts from the apparatus and procedures used in the experimental study were reported in previous tests (Pournik, 2008). Thus this study carried out a sensitivity analysis to define the area of surface evaluation. This was done by gradually excluding rows and columns of data matrix and checking the stability of parameters values. Figure 4 illustrates the process and its results. The exclusion of obvious outliers close to the sample borders formed the general area of analysis. This required an exclusion of $2.54 \mathrm{~cm}(1.0 \mathrm{in})$ at both ends along the length $(X)$. Regarding the height $(Y)$ it was necessary to reject $0.95 \mathrm{~cm}(0.375 \mathrm{in})$ in both laterals. Focusing the area of analysis for conductivity purposes the choice was to adopt the region of back conductivity (Fig. 4). This is the most representative area for conductivity tests because almost all the pressure loss that allows conductivity calculation occurs in this area.

\section{Core preparation evaluation}

The fractures were not hydraulically created in the laboratory, but simulated with flow inserts between each pair of samples. The initial surface analysis of the samples before acid-etching showed 


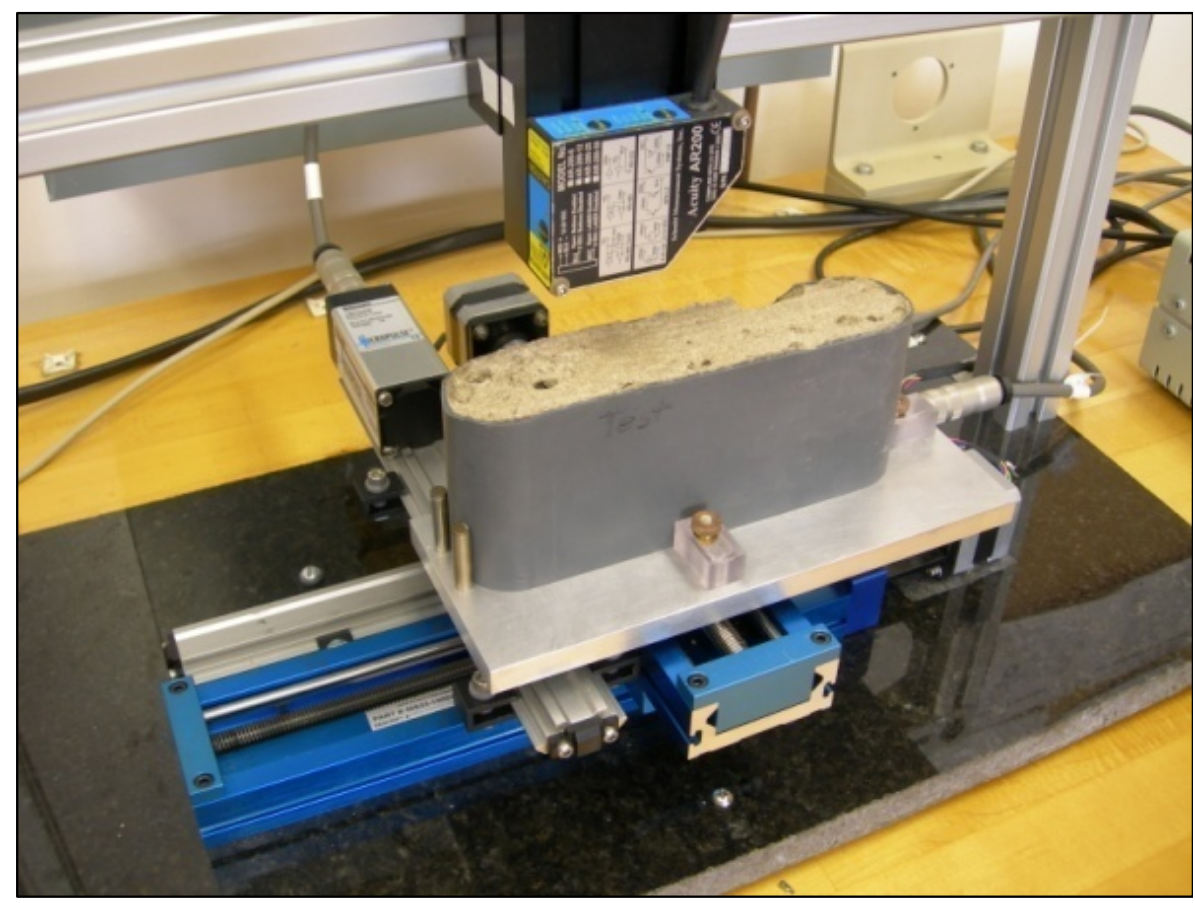

Figure 3 - Profilometer scanning after acid-etching. *Note wormholes on acid-etched face.

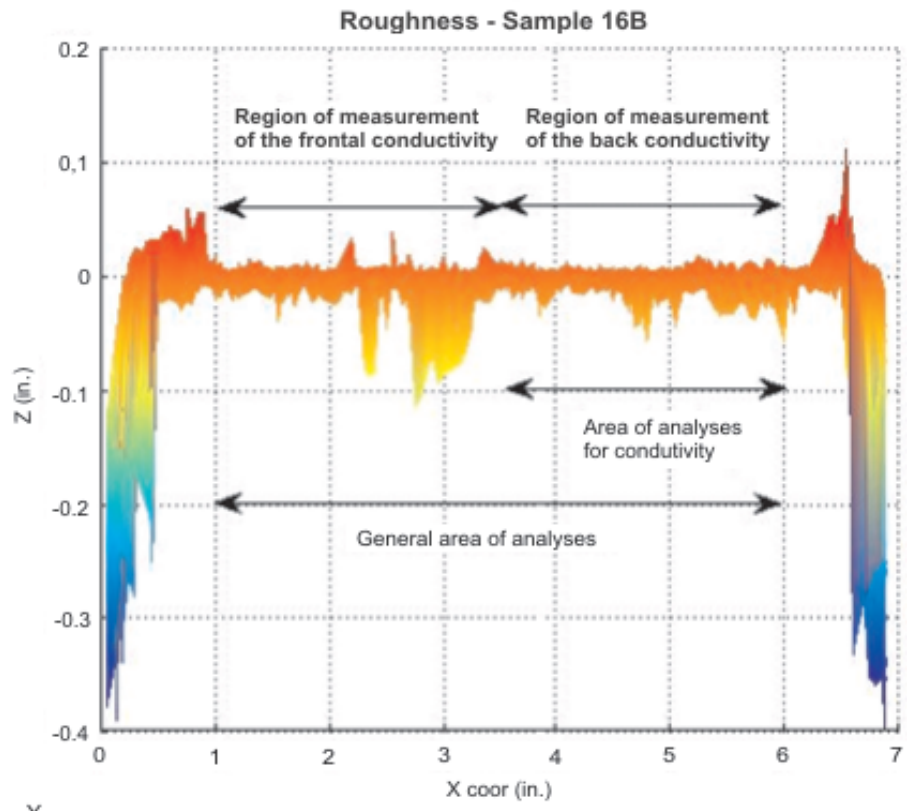

(in.)

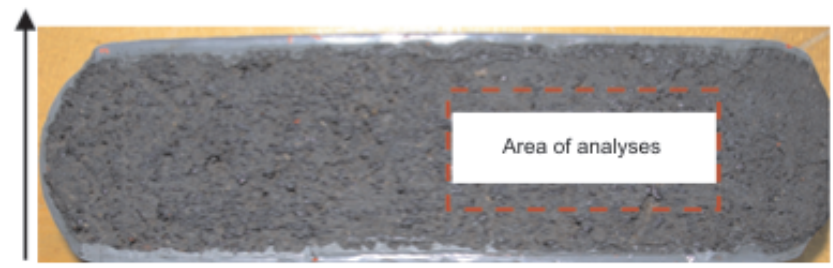

Figure 4 - Illustration of the areas of analyses. *Z scale amplified 10 times. 
some abnormal valleys on the sample borders, which had to be removed for surface analysis before acid-etching by means of excluding a $1.14 \mathrm{~cm}$ strip along the borders. The analysis then showed Sa range from $15 \mu \mathrm{m}$ to $106 \mu \mathrm{m}$, Ssk range from -18.8 to -3.9 , and Sku range from 22.2 to 502.8 . It seems that large range of heights and negative skewness are features of the studied carbonate, while the high kurtosis derived from sample preparation imperfections. A comparison of the fractures surfaces mimic in this study with surfaces of fractures obtained by tension (Brazilian or Lobo Carneiro test) would be useful to verify possible influences of the lab process on the acid-etched surfaces.

\section{Areal surface analysis of the acid-etched surfaces}

The acid-etched surfaces evaluation was based on 3D visualization techniques and descriptive statistics. The aim of the visualization techniques is to enable the human eyes to visualize features that are hard to see without the aid of these techniques. This can be achieved by use of colors, different views, and scale magnification. Figure 5 shows an unfiltered color 3D surface graph, which illustrates hydrodynamic effects on the samples entrance. Figure 6 shows a $Z$ inverted gray 3D surface graph of sample $4 B$, which emphasizes the valleys. Figure 7 shows the roughness of sample 5A. Figures 8 and 9 show the areal autocorrelation function and respective contour line for the sample $5 \mathrm{~A}$ (Str $=0.76)$, while Figures 10 and 11 show the same for the sample $1 \mathrm{~A}(\mathrm{Str}=0.31)$. One can see some spatial orientation even in the more random sample (Figs. 8 and 9).

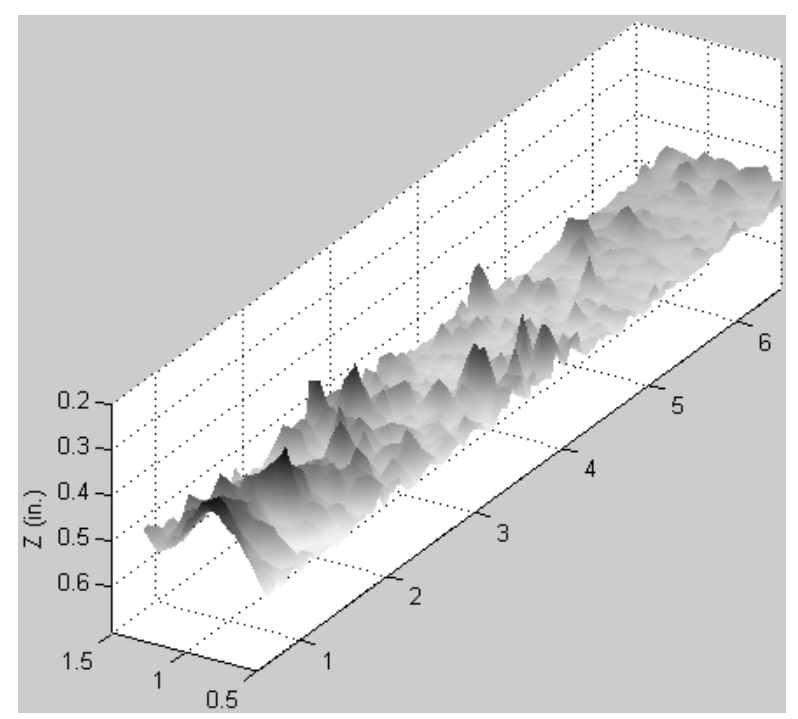

Figure 5 - Unfiltered Z inverted 3D graph - sample 4B. *Z scale amplified 3 times.

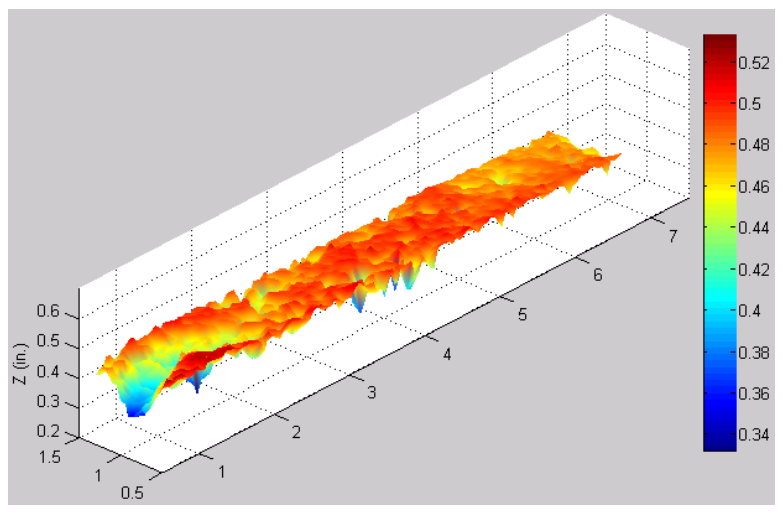

Figure 6 - Unfiltered color 3D surface graph - sample 4B. ${ }^{\star} Z$ scale amplified 3 times. ${ }^{\star \star}$ Note high localized dissolution at the entrance.

Starting the numerical analysis with the measures of central tendency and shape Sa range was $44 \mu \mathrm{m}$ to $597 \mu \mathrm{m}$ with an average of $207 \mu \mathrm{m}$, and $146 \mu \mathrm{m}$ standard deviation (SD). This range is far above the typical roughness values of engineering surfaces. Whitehouse (2002) shows that the Ra values (the 2D equivalent of $\mathrm{Sa}$ ) of these surfaces vary from $0.05 \mu \mathrm{m}$ to $25 \mu \mathrm{m}$. Sq range was $72 \mu \mathrm{m}$ to $1253 \mu \mathrm{m}$, with an average of $349 \mu \mathrm{m}$, and $279 \mu \mathrm{m}$ SD. Ssk varied from -2.8 to -4.4 , with -2.8 mean, while Sku range was 6.1 to 30.8 with 13.7 mean. Thus, large roughness, negative skewness, and high kurtosis are features of the evaluated acid-etched fractures.

The high values of the peak and valleys parameters confirm that acid-etched surfaces are very rough. They present height ranges 39 times or more large than engineering surfaces presented by Blunt \& Jiang (2003). See Table 1. These height ranges reflect on other parameters.

The areal autocorrelation function (AACF) is a useful tool for acquiring information about the spatial properties of surfaces Mainsah et al. (2001). It provided the parameters Sal and Str, as well as the figures of AACF and contour line (relative to the normalized AACF drops to 0.2). The smallest lag length at which the AACF decays to 0.2 , Sal, varied from $1.5 \mathrm{~mm}$ to $24.7 \mathrm{~mm}$ with $6.2 \mathrm{~mm}$ mean and $7.2 \mathrm{~mm}$ SD. Great values of Sal denote the predominance of low frequency components. The texture aspect ratio, Str, range was 0.31 to 0.84 with 0.60 mean and 0.14 SD. Str varies from 0.00 (fully anisotropic surfaces) to 1.00 (fully isotropic surfaces). Any surface with $\mathrm{Sdr}>0.50$ would have significant multi-directional regularity, while those with Sdr $<0.3$ would be strongly anisotropic (Mainsah et al., 2001). The Str values show that most of the studied acid-fracture surfaces are predominantly isotropic. However, as backed by the AACF figures, some spatial orientation can be seen even in the more isotropic surfaces (Fig. 8). 


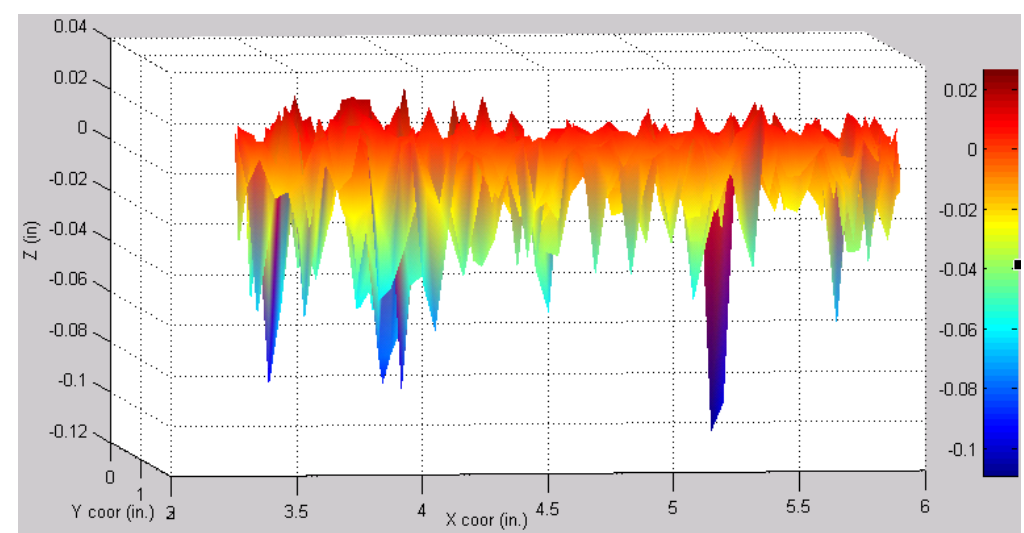

Figure 7 - Roughness - sample $5 \mathrm{~A} .{ }^{*} \mathrm{Z}$ scale amplified 10 times. ${ }^{* \star}$ Note the deep valleys (wormholes).

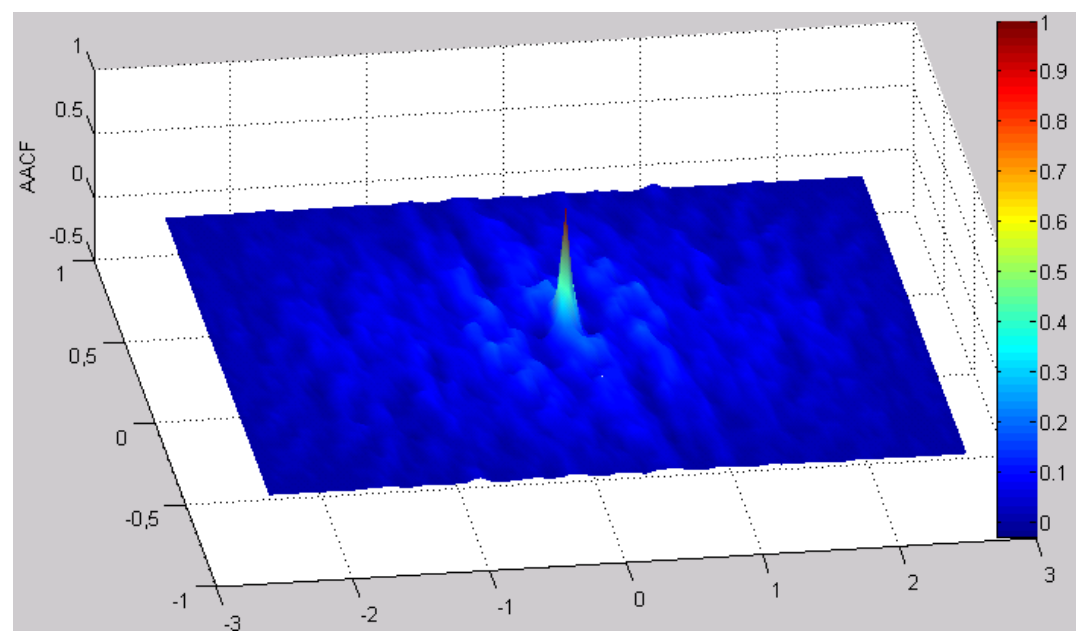

Figure 8 - Areal autocorrelation function (AACF) - sample $5 \mathrm{~A}(\mathrm{Str}=0.76)$.

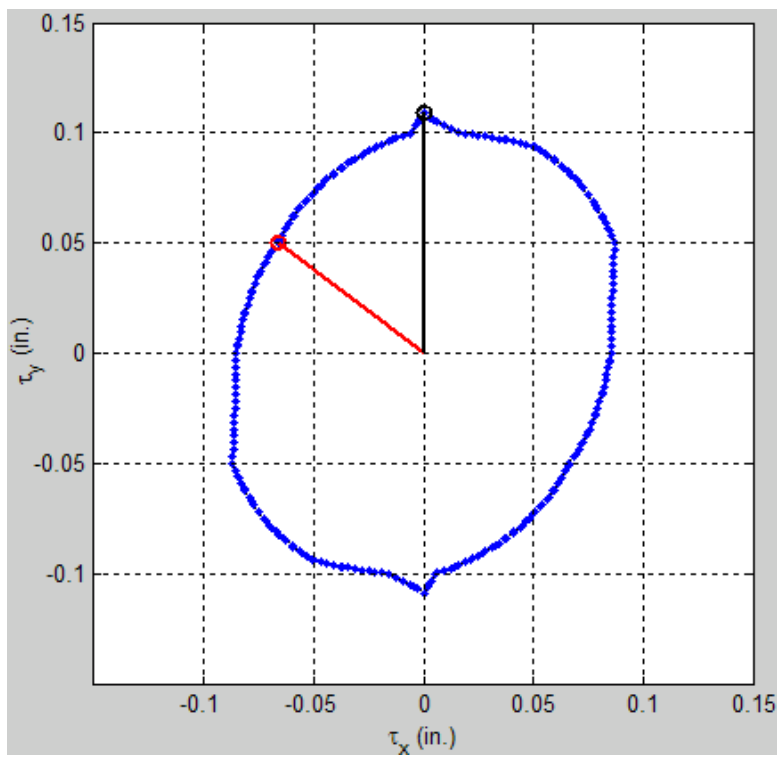

Figure 9 - Contour line for AACF $=0.2-$ sample $5 \mathrm{~A}$. 


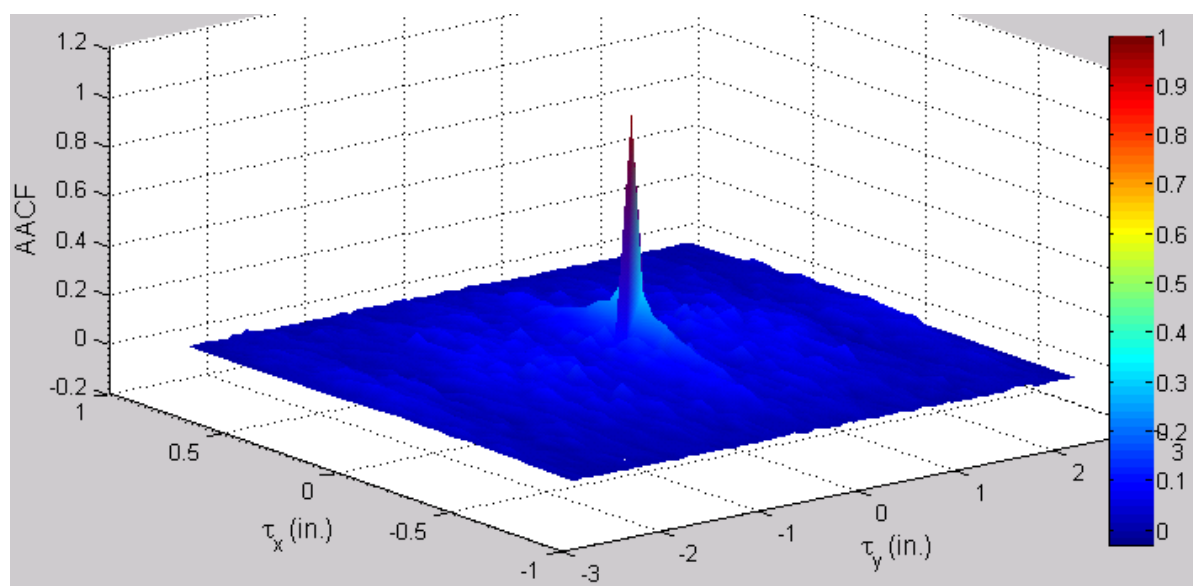

Figure 10 - Areal autocorrelation function (AACF) - sample $1 \mathrm{~A}(\mathrm{Str}=0.31)$.

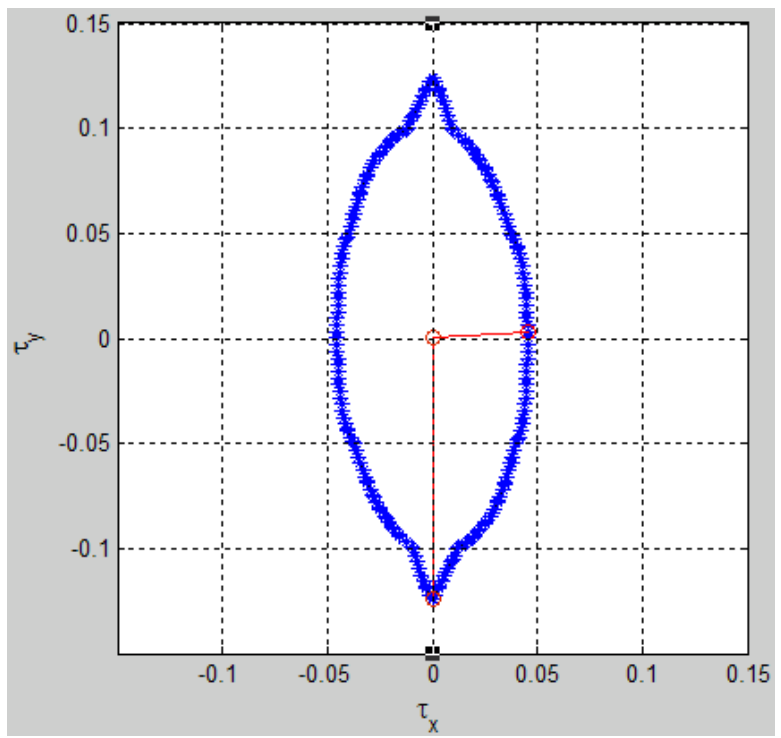

Figure 11 - Contour line for $A A C F=0.2-$ sample $1 \mathrm{~A}$

Table 1 - Amplitude parameters comparison.

\begin{tabular}{|c|c|c|c|}
\hline Parameter/surface & Honed surface & Ground surface & Sample 14 \\
\hline Sampling area & $3 \times 3$ & $2 \times 2$ & $63.5 \times 25.4$ \\
$(\mathrm{~mm} \times \mathrm{mm})$ & & & \\
Height range $(\mu \mathrm{m})$ & 0.00 to 14.37 & 0.00 to 3.22 & -476 to 82 \\
Sq $(\mu \mathrm{m})$ & 1.23 & 0.423 & 82 \\
Ssk & -3.148 & 0.101 & -2.67 \\
Sku & 13.219 & 3.113 & 9.40 \\
Sp $(\mu \mathrm{m})$ & 0.552 & 1.536 & 83.06 \\
Sv $(\mu \mathrm{m})$ & -13.819 & -1.682 & -476 \\
Sz $(\mu \mathrm{m})$ & 14.371 & 3.218 & 560 \\
\hline
\end{tabular}

Source: Blunt \& Jiang (2003) 
Table 2 - Sdr values for four surfaces.

\begin{tabular}{|c|c|c|c|c|}
\hline Parameter/surface & Grit blasted surface & Worn surface & Sample 2B & Sample 6B \\
\hline Sampling area $(\mathrm{mm} \times \mathrm{mm})$ & $9.07 \times 12.14$ & $9.07 \times 12.14$ & $63.5 \times 25.4$ & $63.5 \times 25.4$ \\
Height range $(\mu \mathrm{m})$ & 0.00 to 17.55 & 0.00 to 15.20 & -1015.74 to 217.68 & -1130 to 82 \\
Sdr & $5.51 \%$ & $3.04 \%$ & $0.81 \%^{*}$ & $58.50 \%^{*}$ \\
\hline
\end{tabular}

Source: Blunt \& Jiang (2003). *Minimum and maximum values of Sdr.

The Std values were not considered because according to Mainsah et al. (2001) they are meaningless for surfaces predominantly isotropic (Str > 0.5).

The hybrid parameter Sdq range was 0.08 to 1.13 with 0.37 mean and $0.27 \mathrm{SD}$, while Sdr varied from $0.5 \%$ to $58.5 \%$ with $12.0 \%$ mean and $14.0 \%$ SD. Sdr is the preferred hybrid parameter because it is less affected by scale effects and method of calculus (Mainsah et al., 2001) and appears more tangible to flow along fractures. Table 2 shows $\mathrm{Sdr}$ values for a grit blasted surface and a worn surface (Blunt \& Jiang, 2003) and for samples 2B and 6B.

Sds range was $0.004 \mathrm{~mm}^{-2}$ to $0.049 \mathrm{~mm}^{-2}$ with $0.031 \mathrm{~mm}^{-2}$ mean and $0.013 \mathrm{~mm}^{-2} \mathrm{SD}$. Sds is related to the mode in which the summits deform under load. Low values of Sds may result in higher localized contact stresses ensuing the generation of fines (Michigan Metrology, 2011).

The parameters of the category volume showed high range of values. Those related to the upper part of the material rate curve, in particular Sbi, indicate the chance of fines generation while those related to the lower part of the curve indicate the surface capacity to storage fines and allow its flow (Michigan Metrology, 2011).

This study used the coefficient of linear correlation, r, to estimate the correlation between each pair of parameters. The range of $r$ is -1.00 to 1.00. A value of zero indicates no linear relationship between two variables, whereas the closer the value is to 1 or -1 , the greater the relationship, positive or negative, respectively, between the variables. This is valid only for descriptive purposes because the distributions obtained in this study are not Gaussian (Salkind, 2007). Taking Sq as a reference it showed great correlation $(r>0.70)$ with most of the parameters and low correlation with: Sci $(r=-0.60)$, Sds $(r=-0.55)$, Svi $(r=$ $0.40)$, Sbi $(r=-0.24)$ and $\operatorname{Str}(r=0.05)$. Any of the parameters highly correlated with $\mathrm{Sq}$ could represent the acid-fracture surfaces. However, $\mathrm{Sq}$ is preferred because it is less sensitive to skewed data and to outliers (Salkind, 2007), and to anomalous bright spot on the sample (Malagon Nieto, 2007). Besides, it has been used in previous 2D characterization studies (Patir \& Cheng, 1978; Walsh, 1981; Zimmerman \& Bodvarsson, 1994). Note that Ssk and Sku are not good parameters for correlation because they can lead to misinterpretations when applied to non Gaussian distribution.

The correlation of conductivity at zero closure stress $\left(C_{1}\right)$ measured in the lab with the surface parameters showed very high linear correlation with $\operatorname{Vmc}(r=0.98), S d r(r=0.95)$, Sa $(r=$ $0.95)$, Vvc $(r=0.92)$, and $S q(r=0.91)$. Vmc is a material volume parameter that has significant functional implications (Blunt \& Jiang, 2003). Its high correlation with $\mathrm{C}_{1}$ shows that the texture between $10 \%$ and $80 \%$ of heights (excluding the $10 \%$ highest peaks and the $20 \%$ deepest valleys) determines the conductivity at zero closure stress. One explanation is that the 10\% highest peaks can be broken in the first cycles of closure stress variation (opening and shutting the well) and the 20\% deepest valleys only contribute to flow of fluids from the rock matrix to the fracture. Vmc is also the material available for load support once the top levels of the surfaces are worn away. Thus, the correlation between surface parameters and measured conductivities may be used to search for improved acid-fracture conductivity correlations.

\section{Fracture width calculus}

Fracture width is the main determinant of fracture conductivity at zero closure stress in acid-fracture conductivity correlations (Nierode \& Kruk, 1973; Pournik, 2008). The usual laboratory estimative based on samples mass difference, before and after acid flow, is not accurate because of acid-rock reactions residues. The use of surface topography to calculate fracture width appears to provide more accurate values. The method developed in this study, initially figures out the maximum relative distance between two juxtaposed samples, then computes locally the difference between the maximum and the local height sum, and finally takes the average across the area. The mean of width on the area of analysis was denominated $\mathrm{w}_{\text {topm }}$ (Table 3).

Table 3 - Fracture width ( $\left.w_{\text {topm }}\right)$.

\begin{tabular}{|c|c|c|c|c|c|}
\hline Sample & $\mathbf{1 \& 2}$ & $\mathbf{3 \& 4}$ & $\mathbf{5 \& 6}$ & $\mathbf{7 \& 8}$ & $\mathbf{9 \& 1 0}$ \\
\hline Width $(\mathrm{mm})$ & 0.413 & 1.08 & 1.74 & 1.32 & 1.60 \\
\hline Sample & $\mathbf{1 1 \& 1 2}$ & $\mathbf{1 3 \& 1 4}$ & $\mathbf{1 5 \& 1 6}$ & $\mathbf{1 7 \& 1 8}$ & $\mathbf{1 9 \& 2 0}$ \\
\hline Width $(\mathrm{mm})$ & 1.41 & 0.62 & 1.29 & 0.566 & 0.945 \\
\hline
\end{tabular}




\section{Conductivity tests abnormalities analysis}

In the initial conductivity tests three out of ten behaved far from the expected exponential decay. An attempt to explain these abnormalities with surface characteristics failed because the analysis showed that leaks masked other possible causes of problems. However there were evidences of possible fines generation and partial retention in a couple of tests associated with low values of $\mathrm{Sbi}$, Sds, and Sq (and consequently, by correlation, low values of width and valleys parameters). While low values of Sbi and Sds indicate high chance of fines generation, low values of width and valleys parameters indicate low capacity to storage fines and allow their movement. Although not conclusive, this qualitative analysis revealed the potential of surface characterization use in management of fine particles, an important issue in oil and gas reservoirs.

\section{CONCLUSIONS}

The core samples surfaces before acid-etching showed large range of heights, negative skewness, and very high kurtosis.

The studied acid-etched fracture surfaces showed roughness much larger than usual engineering surfaces, negative skewness, high kurtosis, and an intermediate isotropy - mostly random but with some spatial orientation.

The acid-fractured surfaces can be represented by the rms height, which showed high linear correlation with most of the surface parameters, complemented with the parameters that showed low correlation: texture aspect ratio, bearing index, valley retention index, and density of summits.

The correlation between conductivity at zero closure stress and surface characterization parameters showed high linear correlation for several parameters.

An attempt to explain abnormal behavior in the initial conductivity tests illustrated the potential use of surface characterization in management of fine particles in oil and gas reservoirs.

Three themes for further studies are suggested. The first is to search new acid-fracture conductivity by checking the fitness between surface parameters and measured conductivities. The second is to evaluate the use of surface characterization in management of fine particles in oil and gas reservoirs. The third is to evaluate the surfaces of fractures produced by longitudinal tension (Lobo Carneiro or Brazilian Test) and compare the results with the ones generated in this study.

\section{ACKNOWLEDGMENTS}

The authors gratefully acknowledge the Brazil's National Agency of Petroleum, Natural Gas and Biofuels (ANP) for allowing the use of cores of Quissamã limestone. Special thanks go to Osvaldo de Oliveira Duarte (Petrobras) for his invaluable suggestions.

\section{REFERENCES}

ANTELO LF, POURNIK M, ZHU D \& HILL AD. 2009. Surface Etching Pattern and its Effect on Fracture Conductivity in Acid Fracturing. Paper SPE 119743 presented at the Hydraulic Fracturing Technology Conference, Woodlands, Texas, USA, January, 19-21. 14 pp.

BLUNT L \& JIANG X. 2003. Advanced techniques for assessment surface topography - development of a basis for 3D surface texture standards SURFSTAND. Kogan Page Science, Elsevier Ltd. 340 pp.

BROWN SR \& SCHOLZ CH. 1985. Broad bandwidth study of the topography of natural rock surfaces. J. Geophys. Res., 90(B14): 12575-12582.

GONG M, LACOTE S \& HILL AD. 1998. A New Model of Acid Fracture Conductivity Based on Deformation of Surface Asperities. Paper SPE 39431 presented at the International Symposium on Formation Damage Control, Lafayette, Louisiana, USA, February, 18-19. 15 pp.

HOLMBERG K. 2001. Tribology in reability engineering. The $2^{\text {nd }}$ World Tribology Congress, Vienna, 1, pp. 13-15.

IS0-13565-1. 1998. Geometrical Product Specifications (GPS) - Surface texture: Profile method; Surfaces having stratified functional properties - Part 1: Filtering and general measurement conditions.

IS0/TS CD 25178-2. 2006. Geometrical Product Specifications (GPS) - Surface texture: Areal - Part 2: Terms, definitions and surface texture parameters.

JIANG X, SCOTT PJ, WHITEHOUSE DJ \& BLUNT L. 2007. Paradigm shifts in surface metrology. Part II. The current shift. Proc. R. Soc. A, 463: 2071-2099.

MAINSAH E, GREENWOOD JA \& CHETWYND DG. 2001. Metrology and Properties of Engineering Surfaces. Kluwer Academic Publishers, Boston, 2001. ISBN 0-412-80640-1. 449 pp.

MALAGON NIETO C. 2007. 3D Characterization of Acidized Fracture Surfaces. M.Sc. Dissertation, Texas A\&M University, May 2007. 125 pp.

MICHIGAN METROLOGY. 2011. 3D Surface Roughness and Wear Measurement, Analysis and Inspection. Available on:

$<$ http://www.michmet.com/3d > . Access on: Jan. 25, 2011.

NIERODE DE \& KRUK KF. 1973. An Evaluation of Acid Fluid Loss Additives, Retarded Acids, and Acidized Fracture Conductivity. Paper SPE 4549-MS presented at the 1973 SPE Annual Fall Meeting, Las Vegas, Nevada, USA, 30 September-3 October. 12 pp.

PATIR N \& CHENG HS. 1978. An average flow model for determining effects of three-dimensional roughness on partial hydrodynamics lubrication. J. Lubr. Technol., 100: 12-17. 
POURNIK M. 2008. Laboratory-Scale Fracture Conductivity Created by Acid Etching. Ph.D. Thesis, Texas A\&M University, College Station, Texas, USA. $181 \mathrm{pp}$

SALKIND NJ (Ed.). 2007. Encyclopedia of Measurement and Statistics. Vol. 1, SAGE Publications, Inc., Thousand Oaks, California. 1416 pp.

THOMAS TR. 1999. Rough Surfaces. $2^{\text {nd }}$ edition. Imperial College Press. $278 \mathrm{pp}$.

WALSH JB. 1981. Effect of Pore Pressure and Confining Pressure on
Fracture Permeability. Int. J. Rock Mech. Min. Sci. \& Geomech., 18: 429-435.

WHITEHOUSE D. 2002. Surfaces and their Measurement. Kogan Page Science, Paper Edition. 395 pp.

ZIMMERMAN RW \& BODVARSSON GS. 1994. Hydraulic Conductivity of Rock Fractures. Report LBL-35976, Lawrence Berkeley Laboratory, Berkeley, Ca. 66 pp.

\section{NOTES ABOUT THE AUTHORS}

Valdo Ferreira Rodrigues is a well engineering consultant working in projects in USA and South America and in R\&D projects in LENEP/UENF. B.S. degree in Civil Engineering from the Universidade Estadual de Campinas - UNICAMP, M.Sc. degree in Administration from the Universidade de Alfenas - UNIFENAS, and D.Sc. degree in Reservoir Engineering and Exploration from the Universidade Estadual do Norte Fluminense Darcy Ribeiro - LENEP/UENF. Areas of interest are well engineering, unconventional reservoirs, and surface characterization.

Rodolfo Araujo Victor is a geophysicist at Petrobras. B.S. and M.Sc. degrees in Physics from the Universidade Federal do Espírito Santo - UFES. Areas of interest are geophysics, mathematics, and programming.

Wellington Campos is a well engineering advisor at Petrobras E\&P. Has 26 years of industry experience in oil and gas production. B.S. degree in Civil Engineering from the Universidade Federal de Uberlândia, M.Sc. degree in Petroleum Engineering from the Universidade Federal de Ouro Preto, and Ph.D. degree from the University of Tulsa. Areas of interest are well engineering and oil and gas production.

Ana Catarina da Rocha Medeiros is a consultant in R\&D projects at LENEP/UENF and a professor in several schools. B.S. and Ph.D. degrees in Chemistry from the Universidade Federal do Rio Grande do Norte. Areas of interest are drilling and completion fluids. 